\title{
Shredders prefer soft and fungal-conditioned leaves, regardless of their initial chemical traits
}

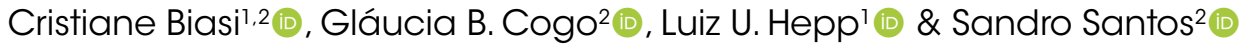

\begin{abstract}
1. Programa de Pós-Graduação em Ecologia, Departamento de Ciências Biológicas, Universidade Regional Integrada do Alto Uruguai e das Missões. Av. Sete de Setembro, 1621, 99709-910 Erechim, RS, Brazil. (cristiane.biasi@gmail.com; luizuhepp@gmail.com)

2. Programa de Pós-Graduação em Biodiversidade Animal, Departamento de Ecologia \& Evolução, Centro de Ciências Naturais e Exatas, Universidade Federal
\end{abstract} de Santa Maria. Av. Roraima, 1000, 97105-900 Santa Maria, RS, Brazil. (glauciabcogo@gmail.com; sandro.santos30@gmail.com)

Received 18 April 2018

Accepted 20 December 2018

Published 14 January 2019

$10.1590 / 1678-4766 e 2019004$

\begin{abstract}
Through field and laboratory experiments we investigated the effects of leaf traits of two tree species and microbial conditioning on the abundance, biomass, and feeding preference of a typical macroinvertebrate shredder. In the field, we compared the association of Phylloicus (Calamoceratidae, Trichoptera) with two tree species commonly found in riparian zones, which are representative of high and low nutritional quality, respectively: Nectandra megapotamica and Chusquea tenella. In the laboratory, we investigated the feeding preference of Phylloicus using unconditioned leaves and leaves conditioned by aquatic fungi. The same tree species used in the field experiment were used in the laboratory. Initially, $C$. tenella leaves were proved to be more nutritious and softer, while $N$. megapotamica leaves were harder and more lignified. The shredders preferred conditioned leaf detritus of reduced toughness (field: $C$. tenella; laboratory: $N$. megapotamica, both conditioned for 14 days). These leaf traits seem to be crucial for the choice process of Phylloicus. After 14 days, N. megapotamica leaves showed a decreased toughness associated with the microbial conditioning, which explained its consumption rate by Phylloicus. In both field and laboratory experiments, we found evidence that Phylloicus is a selective feeding shredder, and that the leaf traits, especially leaf structure (e.g., leaf toughness and lignin content), determine its association and preferences.
\end{abstract}

KEYWORDS. Phylloicus, C:N ratio, feeding preference, leaf toughness, hyphomycetes.

RESUMO. Fragmentadores preferem folhas macias e condicionadas por fungos, independente da sua qualidade química inicial. Nós investigamos em experimento de campo e de laboratório os efeitos das características foliares e condicionamento microbiano de duas espécies de árvores na abundância, biomassa e preferência alimentar de um fragmentador típico. No experimento de campo, comparamos a associação do Phylloicus (Calamoceratidae, Trichoptera) entre duas espécies vegetais, comumente encontradas em zonas ripárias, que são representativas de alta e baixa qualidade nutricional, respectivamente: Nectandra megapotamica e Chusquea tenella. Em experimento de laboratório, investigamos a preferência alimentar de Phylloicus, usando folhas condicionadas e não condicionadas pelos fungos aquáticos. As mesmas espécies vegetais usadas no experimento de campo foram usadas em laboratório. Inicialmente, as folhas de $C$. tenella mostraram-se mais nutritivas e macias, enquanto que as de $N$. megapotamica foram mais duras e lignificadas. Os fragmentadores preferiram o detrito com menor dureza e condicionados pelos fungos (campo: $C$. tenella; laboratório: $N$. megapotamica, ambas condicionadas por 14 dias), ou seja, estes parecem ser os fatores determinantes para a escolha dos Phylloicus. Após 14 dias, as folhas de $N$. megapotamica apresentaram decréscimo na dureza, que está associado ao condicionamento microbiano, e que explicou o padrão de consumo por Phylloicus. Nós encontramos evidências em campo e em laboratório que os Phylloicus são seletivos em relação ao alimento e que as características foliares, especialmente relacionadas à estrutura da folha (ex. dureza foliar e lignina), determinam a associação e a preferência destes fragmentadores.

PALAVRAS-CHAVE. Phylloicus, relação C:N, preferência alimentar, dureza foliar, Hifomicetos.

The input of allochthonous material to forested streams is the primary source of nutrients, energy, and shelter for invertebrates, especially shredders, which consume a significant part of decomposing leaves in aquatic environments (Wallace et al., 1997; PetTit et al., 2012). These organisms are responsible for turning coarse particulate organic matter into fine particulate and dissolved organic matter, making it available to other aquatic invertebrates (WAllace \& WeBster, 1996).

The shredder activity is a significant process in the decomposition of organic matter, representing $50-74 \%$ of the decomposition rates in temperate regions, depending on the plant species (CUFFNEY et al., 1990). In tropical regions, shredders have a low participation in leaf decomposition (BOYERo et al., 2015). Often, tropical streams have $\sim 2.5$ times lower shredders density than temperate regions (BOYERO et al., 2011). However, there are reports of tropical streams with shredders densities similar to temperate streams (CHESHIRE et al., 2005; YULE et al., 2009). In subtropical streams, studies about the importance of shredders to the ecosystem are scarce. Some data suggest that the low density of this trophic group in subtropical streams can be compensated by the large size and biomass of typical shredders (TonIN et al., 2014) when compared with temperate streams. Also, leaf features, microbial activity, and environmental variables acting on streams should be further investigated to determine 
their effects on the shredder community in both tropical and subtropical region (REZENDE et al., 2015; BIASI et al., 2016).

The genus Phylloicus (Müller, 1880) (Calamoceratidae, Trichoptera) is the main shredder of aquatic communities in the subtropical region (TONIN et al., 2014; ToNELlO et al., 2016). Their larval stages are found under leaves on the banks of streams headwaters (WANTZEN \& WAGNER, 2006), feeding and case-building activities of these organisms lead to the typical leaf fragmentation observed in those environments (VANNOTE et al., 1980). Larvae feed on leaves with a higher nutritional quality (RINCÓN \& MARTÍNEZ, 2006), while harder and more lignified leaves with higher polyphenols content are used for case-building (MoretTi et al., 2009; CEREZER et al., 2016).

Intrinsic leaf traits, such as toughness and nutrients and secondary metabolites content, are limiting factors explaining shredders preferences among different leaf species (GRAÇA, 2001; RATNARAJAH \& BARMUTA, 2009; KÖNIG et al., 2014). Harder leaves (i.e., resistant to physical abrasion) and those with a higher concentration of secondary compounds (e.g., polyphenols) may be difficult to consume and restrict shredders activity (RINCón \& MARTINEZ, 2006). Besides, more nutritious leaves (i.e., higher concentrations of nitrogen and low Carbon:Nitrogen ratio - C:N ratio) (KöNIG et al., 2014) are more palatable and appealing to shredders (Mathuriau \& Chauvet, 2002).

The process of microbial conditioning of leaves is known to influence shredders choice (САNHOTO \& GRAÇA, 2008). This process is the transformation of the leaf litter by aquatic hyphomycetes into a more palatable resource for detritivore animals. The colonization by hyphomycetes starts with the conidia fixation on the substrate surface. Afterward, these microorganisms macerate the litter through the activity of their external enzymes, mineralize the organic carbon, convert it into mycelium and reproductive structures, and release fine particulate organic matter (HIEBER \& GESSNER, 2002; CoRnut et al., 2010). This process is affected by physical (e.g., toughness, shape, and roughness) and chemical (e.g., amount of nitrogen) traits of the litter (GuLis et al., 2004; Biasi et al., 2017). The importance of leaf conditioning on shredder preference has been the focus of classic studies which point to a positive effect of microbial colonization on invertebrate feeding (KAUSHIK \& HYNES, 1971; BäRLOCHER \& KENDRICK, 1975). However, some shredders species have shown different patterns. Lepidostoma complicatum (Kobayashi, 1968), Trichoptera and Sternomoera rhyaca (Kuribayashi, Mawatari \& Ishimaru, 1996), Amphipoda, consume unconditioned freshly abscised leaves or even green leaves that retain compounds that would normally prevent herbivory (KoCHI \& YANAI, 2006). Understanding the relationship between Phylloicus and food resources is crucial due to its large size compared with other shredders and because it is the main responsible for leaves fragmentation in subtropical streams (TONIN et al., 2014; ToNELLO et al., 2016).

In this study, we conducted field and laboratory experiments to investigate the effects of leaf traits and microbial conditioning of two tree species on abundance, biomass, and feeding preference of a typical macroinvertebrate shredder. In the field, we compared the association between Phylloicus and two contrasting tree species concerning their leaf traits (Nectandra megapotamica and Chusquea tenella). In the laboratory, we investigated the feeding preference of Phylloicus amongst the same tree species used in the field experiment; leaves conditioned by aquatic fungi and unconditioned leaves were used. The both tree species are found of riparian zones and they are representative of good (N. megapotamica) and poor quality resources (C. tenella) for shredders, so they are good models for testing our hypotheses. We expect that larvae prefer and consume a higher quantity of softer, nutritious, and conditioned leaves. Thus, regardless of the environment field or laboratory, they will prefer items with reduced leaf toughness, lower $\mathrm{C}: \mathrm{N}$ ratio, and conditioned by the microbial community.

\section{MATERIAL AND METHODS}

Leaf sampling. We collected senescent leaves of $N$. megapotamica (Spreng.) Mez. (Lauraceae) and C.tenella Nees (Poaceae) from riparian zones of stream from South Brazil during the 2013 autumn. Both species are native to South America and the choice was based on their wide occurrence and abundance in stream riparian zones. The leaves were air-dried at room temperature $\left(\sim 20^{\circ} \mathrm{C}\right)$ until the beginning of the experiments. Approximately $5 \mathrm{~g}$ of leaves of each species were used to perform the leaf traits characterization.

Leaf traits. The leaf traits characterization of both tree species was performed prior to the beginning of the experiments. The leaves $(1 \mathrm{~mm})$ were ground to powder in an analytical mill to estimate the concentration of nitrogen, polyphenol, lignin, cellulose, carbon, and metals. The nitrogen concentration was estimated according to the Kjeldahl method (FLINDT \& LILLEBO, 2005). For polyphenol extraction, samples were exposed to the Folin-Denis reagent and sodium carbonate. The polyphenols concentration was estimated through OD (optical density); results were read in a $725-\mathrm{nm}$ wavelength spectrophotometer (SCHWARZE, 1958). Approximately $3 \mathrm{~g}$ of leaves of each species was incinerated in a muffle furnace (at $550^{\circ} \mathrm{C}$, for 4 hours) for the determination of the ash-free dry mass (AFDM). The resulting inorganic material was diluted in $\mathrm{HNO}_{3}\left(1 \mathrm{~mol} \mathrm{~L}^{-1}\right)$ and analyzed using an atomic absorption spectrophotometer for metals determination (calcium, magnesium, and potassium). The carbon concentration in leaves was estimated through the results of the AFDM analysis, assuming that $47 \%$ of the total organic matter is composed of carbon (WeSTLAKE, 1963). Lignin and cellulose percentages were estimated by the detergent acid method (VAN SOEST, 1993). Leaf toughness was measured with a penetrometer (2.5-mm diameter). The pressure $(\mathrm{P})$ required for the metal pin to penetrate in the leaf was calculated by $\mathrm{P}=\mathrm{F} / \mathrm{A}$ ( $\mathrm{F}$ is the water volume plus 
the holder weight with the metal pin and the beaker glass weight divided by the area $\mathrm{A}$ in which the force is applied).

\section{Field Approach - Phylloicus abundance and biomass in streams}

Study area. The experiment was conducted in two small-order streams in southern Brazil (Tab. I). The climate is subtropical, with an average annual temperature of $17.6{ }^{\circ} \mathrm{C}$ and average annual rainfall of $1,912 \mathrm{~mm}$. The typical vegetation is an extension of the Atlantic Forest, with transitional features between the Semi Decidual Seasonal Forest and Araucaria Forest (OliveIRA-Filho et al., 2006). The plant formation includes temperate species such as Araucaria angustifolia (Bertol.) Kuntze, Vernonia discolor (Spreng.) Less, and Piptocarpha angustifolia (Dusen ex Malme). Deciduous species includes Apuleia leiocarpa (Vog.) Macbr, Nectandra megapotamica (Spreng.) Mez, Sebastiania brasiliensis (Spreng.), and Campomanesia xanthocarpa (O. Berg.).

The streams have established riparian vegetation (approximately $70 \%$ canopy) and a stony substrate with frequent riffles, pools, and leaf banks. During the experiments, the streams had a width range of $1.5-2.8 \mathrm{~m}$ and a depth range of $0.4-0.9 \mathrm{~m}$. The water was well-oxygenated and had mild temperature ranges (Tab. I). All analyzed variables were similar in both streams, except for electrical conductivity which was higher in Dourado stream (Tab. I).

Experimental design. The field experiment lasted 14 days and was conducted during summer, from December 2013 to January 2014. The experimental design was equally established in both streams. We used $3 \pm 0.1 \mathrm{~g}$ of dried leaves of $N$. megapotamica and $C$. tenella to producing 16 litter bags of $10-\mathrm{mm}$ mesh size $(15 \times 20 \mathrm{~cm})$. The litter bags were randomly attached to the streams in sites with moderate or no currents with proper leaf accumulation to obtain the fungal-

Tab. I. Environmental variables (mean $\pm \mathrm{SE} ; n=3$ ) measured in Dourado and Horto stream, Rio Grande do Sul, Brazil during the experiment period. Different letters indicate significant differences $(t$ test, $\mathrm{p}<0.05)$

\begin{tabular}{lcc}
\hline & \multicolumn{2}{c}{ Streams (geographic coordinates) } \\
\hline $\begin{array}{l}\text { Variables } \\
\text { Dourado }\end{array}$ & $\begin{array}{c}\text { Horto } \\
\left(\mathrm{mg} \mathrm{L}^{-1}\right)\end{array}$ & $11.2 \pm 0.1^{\mathrm{a}}$ \\
$\begin{array}{l}\text { Water temperature } \\
\left({ }^{\circ} \mathrm{C}\right)\end{array}$ & $\left.10.5 \pm 0.1^{\mathrm{a}} 07^{\prime} \mathrm{S} ; 52^{\circ} 16^{\prime} 12^{\prime \prime} \mathrm{W}\right)$ & $\left(27^{\circ} 43^{\prime} 01^{\prime \prime} \mathrm{S} ; 52^{\circ} 18^{\prime} 30^{\prime \prime} \mathrm{W}\right)$ \\
$\begin{array}{l}\text { Electrical conductividy } \\
\left(\mu \mathrm{S} \mathrm{cm}^{-1}\right)\end{array}$ & $16.2 \pm 0.01^{\mathrm{a}}$ & $18.7 \pm 0.01^{\mathrm{a}}$ \\
$\begin{array}{l}\text { Turbidity (NTU) } \\
\text { pH }\end{array}$ & $6.1 \pm 1.4^{\mathrm{a}}$ & $3.8 \pm 1.2^{\mathrm{b}}$ \\
$\begin{array}{l}\text { Total nitrogen } \\
\left(\mathrm{mg} \mathrm{L}^{-1}\right)\end{array}$ & $6.9 \pm 0.0^{\mathrm{a}}$ & $5.1 \pm 1.3^{\mathrm{a}}$ \\
$\begin{array}{l}\text { Total organic carbon } \\
\left(\mathrm{mg} \mathrm{L}^{-1}\right)\end{array}$ & $0.6 \pm 0.0^{\mathrm{a}}$ & $7.4 \pm 0.2^{\mathrm{a}}$ \\
$\begin{array}{l}\text { Total inorganic carbon } \\
\left.(\mathrm{mg} \mathrm{L})^{-1}\right)\end{array}$ & $4.2 \pm 0.6^{\mathrm{a}}$ & $0.6 \pm 0.0^{\mathrm{a}}$ \\
\hline
\end{tabular}

conditioned leaves. After a 14-day incubation, four litter bags of each species were randomly taken from each stream and transported to the laboratory. Samples were washed over a $0.25 \mathrm{~mm}$ sieve to remove sediment and invertebrates associated to the detritus. The associated shredders were identified to the generic level (Phylloicus) using taxonomic keys (Pes et al., 2005; MugnaI et al., 2010). The larvae were oven dried (at $65^{\circ} \mathrm{C}$, for $48 \mathrm{~h}$ ) and weighed to biomass determination.

\section{Laboratory approach - Feeding preference of Phylloicus}

Phylloicus sampling. Phylloicus individuals were collected from a small order stream (29 $39^{\prime} 49^{\prime \prime}$, $53^{\circ} 44^{\prime} 34^{\prime \prime} \mathrm{W}$ ) using a hand net and visual search across the accumulated leaf litter. Individuals were transported to the laboratory in a refrigerated cooler containing leaves and water from the stream. In the laboratory, individuals were acclimated for $24 \mathrm{~h}$ (12L:12D photoperiod) in individual compartments with a fine gravel substrate and filtered water from the stream (filtered through a 6 - $\mu \mathrm{m}$ pore size filter) under controlled temperature $\left(18^{\circ} \mathrm{C}\right)$. Animals were not fed during acclimation. Only larvae with body size/head capsule rate range of $0.87-1.20 \mathrm{~mm}$ were used in the experiments.

Leaf preference experiment. The feeding preference of Phylloicus when exposed to leaves of two plant species was conducted using unconditioned leaves and conditioned by aquatic fungi. Each Phylloicus individual was kept in a plastic cup $(36 \times 8 \mathrm{~cm})$ with $100 \mathrm{~mL}$ of filtered stream water and fine gravel substrate. Leaf discs were cut with a 12-mm diameter cork borer, avoiding primary and secondary veins. The experiment was performed with fifty-six replicas, containing one larva and detritus of the two plant species $(N$. megapotamica and C. tenella). Each larva received two discs of both conditioned (14 days of exposure in the stream in litter bag with $500 \mu \mathrm{m}$ mesh size) and unconditioned leaves of the two species. To estimate the leaf mass loss due to leaching and microorganisms action, control discs (one disc for each treatment) were kept in fine mesh packets $(500 \mu \mathrm{m})$ attached to the cups surface impairing the animals access for seven days. At the end of the experiment, the remaining discs (experimental and control) were dried in an oven (at $65^{\circ} \mathrm{C}$, for $48 \mathrm{~h}$ ) and weighed to dry mass estimation. The shredders preference was estimated by subtracting the weight of the control discs by the weight of the consumed discs. The larvae were deposited in the scientific collection of the Carcinology Laboratory of the Universidade Federal de Santa Maria, RS.

Data analyses. The chemical variables of both plant species were tested by a $t$-test. The abundance and biomass of Phylloicus and leaf toughness (field experiment) of each plant species were compared by a two-way ANOVA, using the streams as factors. The consumption data of both plant species from the laboratory experiment were compared by a two-way ANOVA, using the conditioning time as a 
factor. Leaf toughness from the laboratory experiment was compared by a $t$-test. The abundance and biomass data were log-transformed $(\mathrm{x}+1)$. All analyses were performed on $\mathrm{R}$ software (R Development CoRe TEAm, 2012).

\section{RESULTS}

Leaf traits. There were differences between the initial physical and chemical traits of both plant species, except for polyphenols and cellulose (Tab. II). Chusquea tenella leaves had higher concentrations of nitrogen, magnesium, and potassium, while $N$. megapotamica leaves were harder and had higher lignin, carbon, $\mathrm{C}: \mathrm{N}$ ratio, and calcium content (Tab. II). In the field experiment, leaf toughness of $C$. tenella was lower $\left(F_{1,24}=122.6, \mathrm{p}<0.001\right.$; Fig. 1A). In the laboratory experiment, $N$. megapotamica had lower leaf toughness after 14 days $(t=1.2, \mathrm{df}=9, \mathrm{p}=0.004$; Fig. 1B). The streams had no effect on the leaf toughness lost $\left(F_{2,24}=0.1, \mathrm{p}=0.46\right)$.
Field approach - Phylloicus abundance in streams. There were variations in the abundance of Phylloicus depending on which plant species it was associated $\left(F_{1,8}=\right.$ $6.95, \mathrm{p}=0.014)$ (Fig. 2A). Phylloicus individuals were more abundant when associated with $C$. tenella $(70 \%)$. In the Horto stream, the total abundance of Phylloicus was 58\% $\left(F_{1,8}=16.0, \mathrm{p}=0.001\right)$. There was no relationship between leaf species and neither one of the streams $\left(F_{1,8}=0.5, \mathrm{p}=\right.$ $0.58)$. Shredders biomass varied according with the plant species $\left(F_{1,8}=5.0, \mathrm{p}=0.02\right)$, but no difference was observed between streams $\left(F_{1,8}=3.3, \mathrm{p}=0.09\right)$ (Fig. 2B).

Laboratory approach - Feeding preference of Phylloicus. Phylloicus had a feeding preference for 14-day conditioned $N$. megapotamica $\left(F_{1,264}=67.1, \mathrm{p}=0.001\right.$; Fig. 3). The unconditioned disc leaves of $C$. tenella and $N$. megapotamica were also consumed by shredders.

Tab. II. Leaf characteristics (mean $\pm \mathrm{SE} ; \mathrm{n}=3$ ) of the leaves of Chusquea tenella and Nectandra megapotamica before incubation in the streams (C:N, Carbon:Nitrogen ratio; DM, dry mass; DO, optical density).

\begin{tabular}{|c|c|c|c|c|}
\hline & C. tenella & N. megapotamica & $t(d f=8)$ & $\mathrm{p}$ \\
\hline Leaf toughness $\left(\mathrm{kgf} \mathrm{cm}^{-2}\right)$ & $37.2 \pm 2.1$ & $49.2 \pm 2.8$ & -19.1 & $<0.001$ \\
\hline$\%$ Nitrogen & $2.2 \pm 0.0$ & $1.5 \pm 0.0$ & 17.1 & $<0.001$ \\
\hline$\%$ Carbon & $46.5 \pm 0.5$ & $57.2 \pm 0.2$ & -9.1 & 0.006 \\
\hline $\mathrm{C}: \mathrm{N}$ ratio & $20.4 \pm 0.3$ & $38.1 \pm 0.5$ & 19.0 & $<0.001$ \\
\hline \% Lignin & $6.9 \pm 1.0$ & $29.5 \pm 1.9$ & 7.4 & 0.008 \\
\hline$\%$ Cellulose & $7.8 \pm 0.8$ & $6.4 \pm 0.0$ & 1.7 & 0.117 \\
\hline Phenolic (DO g $\left.{ }^{-1} \mathrm{DM}\right)$ & $170.3 \pm 5.9$ & $167.2 \pm 3.7$ & 0.6 & 0.307 \\
\hline Calcium (mg g $\left.{ }^{-1} \mathrm{DM}\right)$ & $1.1 \pm 0.0$ & $3.8 \pm 0.1$ & 26.8 & $<0.001$ \\
\hline Magnesium (mg g $\left.{ }^{-1} \mathrm{DM}\right)$ & $2.2 \pm 0.0$ & $0.2 \pm 0.0$ & 243.1 & $<0.001$ \\
\hline Potassium (mg g-1 DM) & $6.8 \pm 0.0$ & $3.3 \pm 0.0$ & 382.0 & $<0.001$ \\
\hline
\end{tabular}
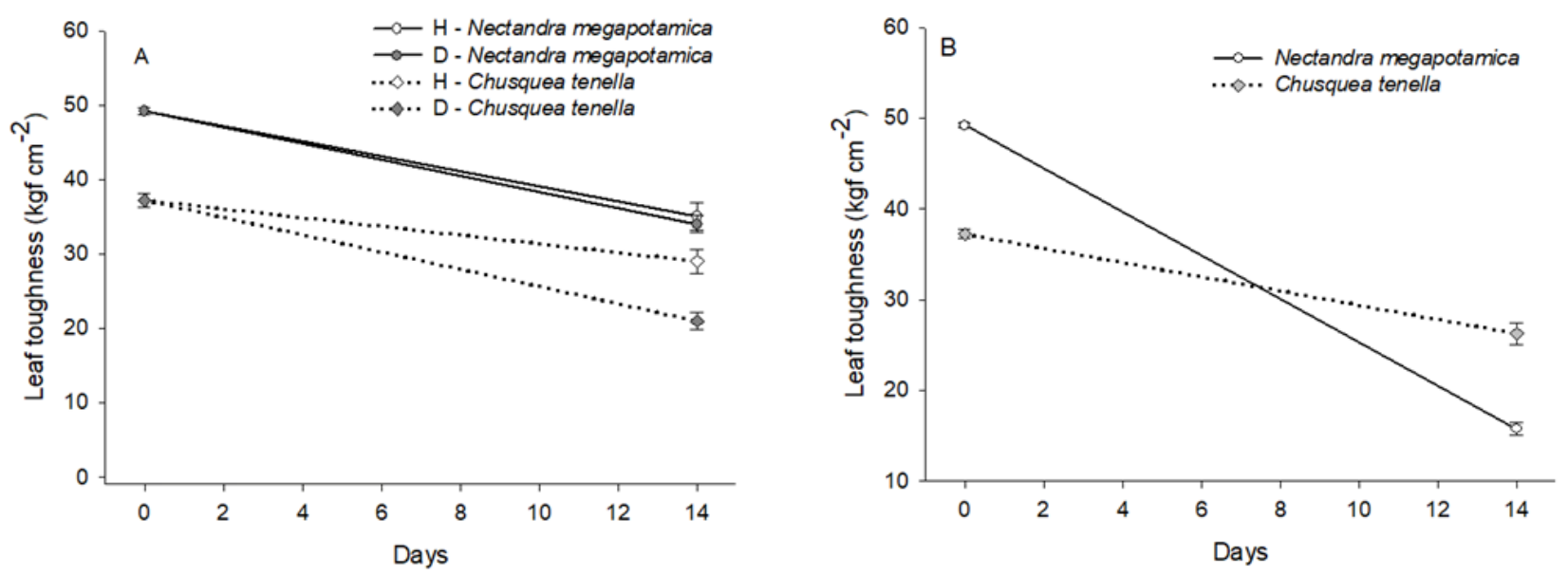

Fig. 1. Leaf toughness values (mean $\pm \mathrm{SE}$ ) for Nectandra megapotamica and Chusquea tenella and in (A) during the period of experiment in the field and (B) during the period of experiment in the laboratory (H, Horto stream; D, Dourado stream). 

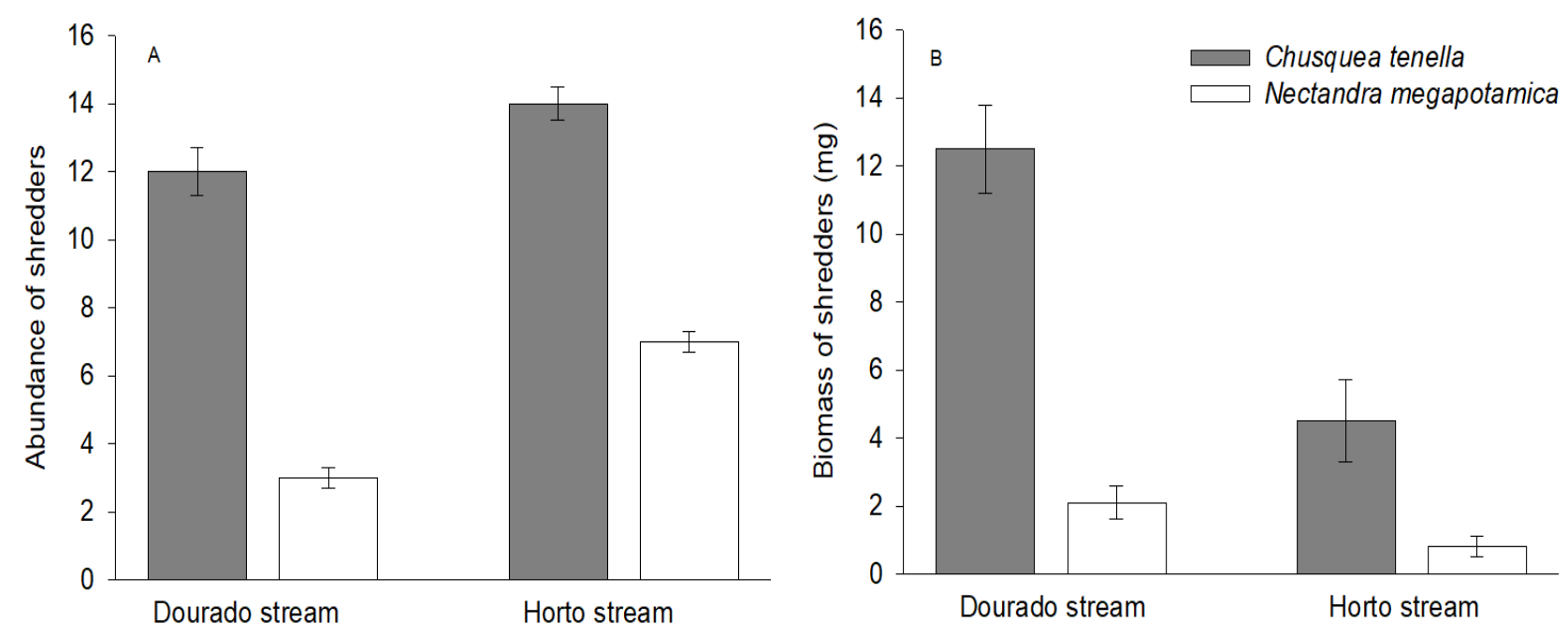

Fig. 2. Abundance and Biomass of Phylloicus (mean \pm SE) associated with decaying leaves of Chusquea tenella and Nectandra megapotamica for 14 days of incubation in Dourado and Horto streams, Rio Grande do Sul, Brazil.

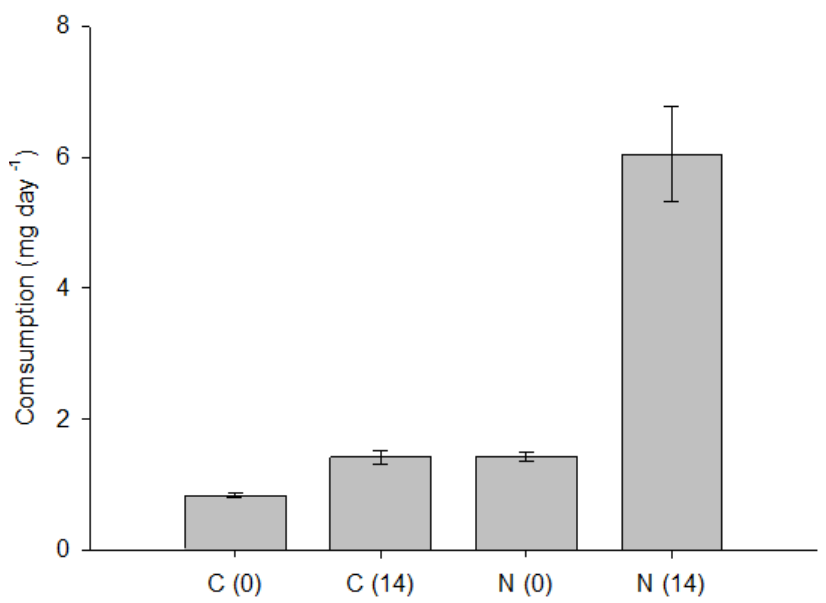

Fig. 3. Consumption (mean $\pm \mathrm{SE}$ ) of Chusquea tenella and Nectandra megapotamica by Phylloicus $(n=54)$ at different stages of microbial conditioning $(\mathrm{C}, C$. tenella; $\mathrm{N}, N$. megapotamica; 0 , unconditioned discs; 14 , discs with 14 days conditioning).

\section{DISCUSSION}

Both evaluated plant species differed in their nutritional traits. While $C$. tenella leaves are more palatable and nutritious, $N$. megapotamica leaves are harder, more lignified, and have a more resistant cuticle (ZANON et al., 2009). These leaf traits are essential to the fragmentation process in streams; $C$. tenella will have a faster decomposition rate than $N$. megapotamica since it is more easily consumed by shredders; $N$. megapotamica will remain longer in the streams, so it will be later consumed by shredders. As expected, the leaf toughness of both plant species, in the field and in the laboratory, decreased with time. This decreased toughness promotes a consequent reduction in the friction resistance of leaves (RATNARAJAH \& BERMUTA, 2009). Thus, detritus with increased immersion time in the stream become softer and more palatable for shredders (LigEIRo et al., 2010;
BIASI et al., 2013). However, N. megapotamica leaves showed a marked decrease in toughness after 14 days of laboratory experiment, which did not happen in the field. This result was unexpected and suggests intense microbial conditioning of $N$. megapotamica leaves.

Phylloicus individuals were more abundant and had higher biomass when associated with $C$. tenella leaves throughout the field experiment. Based on the previously estimated leaf traits, $C$. tenella leaves are more palatable for these shredders. Detritus of $C$. tenella had a higher amount of nitrogen and a lower $\mathrm{C}: \mathrm{N}$ ratio, lignin content, and leaf toughness during the field experiment. It has been demonstrated that there is higher shredder density associated with decaying leaves with higher nutritional quality (RINCÓN \& Martinez, 2006; Graça \& Cressa, 2010; Garcia et al., 2012; BRUDER et al., 2014; KöNIG et al., 2014). There is often a negative correlation between fragmentation rates and leaf toughness (ABELHO, 2008; Li et al., 2009) and lignin quantity (Wright \& COVICH, 2005), which are important physical attributes promoting the resistance of leaves (RATNARAJAH \& BARMUTA, 2009). High consumption rates of fast decomposing leaves are also related to a larger shredder size (GoNZÁLEZ \& GRAÇA, 2003). Chusquea tenella leaves have features that allow a fast association of shredders, such as low lignin: $\mathrm{N}$ and low toughness, which explain the higher Phylloicus abundance and biomass and probably the faster leaf breakdown. Thus, the higher Phylloicus abundance and biomass when associated with $C$. tenella is related to the leaf traits.

In the laboratory experiment, shredders had a preference for the less palatable species (N. megapotamica). However, they preferred 14-day conditioned leaves, which had a significant toughness reduction. In this case, the preference of Phylloicus for N. megapotamica is related to leaf traits. The decreased leaf toughness along with the increased conditioning time explained this consumption 
pattern. There are reports that the microbial conditioning, especially hyphomycetes, promotes increased palatability of detritus as it influences the breakdown of structural leaf compounds and reduces its toughness (PEARSON \& CONNOLLY, 2000; GraÇA et al., 2001; Assmann et al., 2011).

In both field and laboratory experiments, shredders had a preference for more conditioned detritus with reduced toughness, which seem to be determining factors for the Phylloicus choice. These parameters are interrelated, leaf toughness tends to decrease as microbial colonization is established, which was observed in the leaves of both species (Foucreau et al., 2013). Unconditioned leaves of C. tenella were consumed by Phylloicus, while unconditioned leaves of $N$. megapotamica were used only to case repairing. This is probably related to the fact that $N$. megapotamica is a more resistant low-quality resource and it was only consumed by Phylloicus when its toughness is reduced and the conditioning time is increased. As for C. tenella, due to its high initial quality, it was consumed even without being conditioned by the microbial community.

Laboratory studies have shown that shredders prefer consuming conditioned leaves (CHUNG \& SUBERKROPP, 2009) with higher nitrogen content (RINCÓN \& MARTíNEZ, 2006; CASOTTI et al., 2015) and lower toughness (Li et al., 2009). As for the case-building, they prefer leaves with higher toughness and lignin and polyphenols content (MORETTI et al., 2009; CEREZER et al., 2016). This corroborates our results; although we did not quantify it, we observed that some Phylloicus individuals used lower quality leaf discs with higher toughness for case repairing, and used leaves of better quality for feeding.

In both field and laboratory experiments, we found evidence that Phylloicus is selective concerning food choice. These organisms select detritus with reduced toughness and conditioned by the microbial community. Leaf traits characteristics of both tree species explained the association of shredders with the detritus, even experiencing a reversal preference between the field (higher association with $C$. tenella) and laboratory ( $N$. megapotamica was the most consumed species) experiments. In conclusion, our results indicate that leaf traits determine the association, feeding preference, and biomass of Phylloicus. This study points out to the importance of combining laboratory tests with field observations. Our results also support the importance of conservation of riparian vegetation since it provides a diversity of detritus to aquatic communities. We demonstrated a strong relationship between shredders (Phylloicus) and the plant material entering the streams. This relationship demonstrates that alterations in the allochthonous material can affect the food activity of shredders which can affect the secondary production and the food web in low-order streams. Importantly, ecosystem processes that are performed by shredders, such as leaf decomposition, can be also altered.

Acknowledgments. We thank Coordenação de Aperfeiçoamento de Pessoal de Nivel Superior (CAPES) for the scholarships to CB and GBC as well as Conselho Nacional de Desenvolvimento Cientifico e Tecnológico
(CNPq) for the productivity scholarship for SS (proc. \#311142/2014-1) and LUH (proc. \#305203/2017-7). We also thank Mr. Graciano Sonego for opening his property for us to collect plant and animals species.

\section{REFERENCES}

Abelho, M. 2008. Effects of leaf litter species on macroinvertebrate colonization during decomposition in a Portuguese stream. International Review of Hydrobiology 93:358-371.

Assmann, C.; Rinke, K.; Nechwatal, J. \& Elert, E. V. 2011. Consequences of the colonisation of leaves by fungi and oomycetes for leaf consumption by a gammarid shredder. Freshwater Biology 56:839-852.

BÄRLOCHER, F. \& KENDRICK, B. 1975. Leaf-conditioning by microorganisms. Oecologia 20:359-362.

Biasi, C.; Cerezer, C. \& Santos, S. 2016. Biological colonization and leaf decomposition in a subtropical stream. Ecologia Austral 26:189-199.

Biasi, C.; Graça, M. A. S.; Santos, S. \& Ferreira, V. 2017. Nutrient enrichment in water more than in leaves affects aquatic microbial litter processing. Oecologia 184:555-568.

Biasi, C.; Tonin, A. M.; Restello, R. M. \& Hepp, L.U. 2013. Colonisation of leaf litter by Chironomidae (Diptera): influence of chemical quality and exposure duration in a Neotropical stream. Limnologica 43:427-433.

Boyero, L.; Pearson, R. G.; Dudgeon, D.; GraÇa, M. A. S.; Gessner, M. O.; Albariño, R.; Ferreira, V.; Yule, C. M.; Boulton, A. J.; Arunachalam, M.; Callisto, M.; Chauvet, E.; Ramírez, A.; Chará, J.; Moretti, M. S.; Gonçalves, J. F. Jr.; Helson, J. E.; CharÁ-Serna, A.; Encalada, A. C.; Davies, J. N.; Lamothe, S.; CorneJo, A.; Li, A. O. Y.; Buria, L. M.; Villanueva, V. D.; Zúñiga, M. C. \& Pringle, C. M. 2011. Global distribution of a key trophic guild contrasts with common latitudinal diversity patterns. Ecology 92:1839-1848.

Boyero, L.; Pearson, R. G.; Gessner, M. O.; Dudgeon, D.; Ramírez, A.; Yule, C. M.; Callisto, M.; Pringle, C. M.; Encalada, A. C.; Arunachalam, M.; Mathooko, J.; Helson, J. E.; Rincón, J.; Bruder, A.; Cornejo, A.; Flecker, A. S.; Mathuriau, C.; M'Erimba, C.; Gonçalves, J. F. JR.; Moretti, M. \& Jinggut, T. 2015. Leaf-litter breakdown in tropical streams: is variability the norm? Freshwater Science 34:759-769.

Bruder, A.; Schindler, M. H.; Moretti, M. S. \& Gessner, M. O. 2014. Litter decomposition in a temperate and a tropical stream: the effects of species mixing, litter quality and shredders. Freshwater Biology 59:438-449.

Canhoto, C. \& GraÇA, M. A. S. 2008. Interactions between fungi and stream invertebrates: back to the future. Novel Techniques and Ideas in Mycology. Fungal Diversity Research Series 20:305-325.

Casotti, C. G.; Kiffer, W. P. Jr. \& Moretti, M. S. 2015. Leaf traits induce the feeding preference of a shredder of the genus Triplectides kolenati, 1859 (Trichoptera) in an Atlantic Forest stream, Brazil: a test with native and exotic leaves. Aquatic Insects 36:43-52.

Cerezer, C.; Biasi, C.; Cogo, G. B. \& Santos, S. 2016. Avoid predation or take risks in basic activities? Predator-prey relationship in subtropical streams between decapods and caddisflies. Marine and Freshwater Research 67:1880-1887.

Cheshire, K.; Boyero, L. \& Pearson, R. G. 2005. Food webs in tropical Australian streams: shredders are not scarce. Freshwater Biology 50:748-769.

Chung, N. \& Suberkropp, K. 2009. Contribution of fungal biomass to the growth of the shredder, Pycnopsyche gentilis (Trichoptera: Limnephilidae). Freshwater Biology 54:2212-2224.

Cornut, J.; Elger, A.; Lambrigot, D.; Marmonier, P. \& Chauvet, E. 2010. Early stages of leaf decomposition are mediated by aquatic fungi in the hyporheic zone of woodland streams. Freshwater Biology 55:2541-2556.

Cuffney, T. F.; Wallace, J. B. \& Lugthart, G. J. 1990. Experimental evidence quantifying the role of benthic invertebrates in organic matter dynamics of headwater streams. Freshwater Biology 23:281-299.

FlindT, M. R. \& Lillebo, A. I. 2005. Determination of total nitrogen and phosphorus in leaf litter. In: GraçA, M. A. S.; BÄrlocher, F. \& Gessner, M. O. eds. Methods to Study Litter Decomposition: A Practical Guide, p. 53-59. 
Foucreau, N.; Puijalon, S.; Hervant, F. \& Piscart, C. 2013. Effect of leaf litter characteristics on leaf conditioning and on consumption by Gammarus pulex. Freshwater Biology 58:1672-1681.

Garcia, L.; Richardson, J. S. \& Pardo, I. 2012. Leaf quality influences invertebrate colonization and drift in a temperate rainforest stream. Canadian Journal of Fisheries and Aquatic Sciences 69:1663-1673.

GRAÇA, M. A. S. 2001. The role of invertebrates on leaf decomposition in streams: a review. International Review of Hydrobiology 86:383-393.

GraçA, M. A. S. \& Cressa, C. 2010. Leaf quality of some Tropical and Temperate tree species as food resource for stream shredders. International Review of Hydrobiology 95:27-41.

Graça, M. A. S.; Cressa, C.; Gessner, M. O.; Feio, M. J.; Callies, K. A. \& BARRIOS, C. 2001. Food quality, feeding preferences, survival and growth of shredders from temperate and tropical streams. Freshwater Biology 46:947-957.

GonzÁlez, J. M. \& GraÇA, M. A. S. 2003. Conversion of leaf litter to secondary production by the shredder caddisfly Sericostoma vittatum. Freshwater Biology 48:1578-1592.

Gulis, V.; Rosemond, A. D.; Suberkropp, K.; Weyers, H. S. \& Benstead, J. P. 2004. The effect of nutrient enrichment on the decomposition of wood and associated microbial activity in streams. Freshwater Biology 49:1437-1447.

Hieber, M. \& GeSSNER, M. O. 2002. Contribution of stream detritivores, fungi, and bacteria to leaf breakdown based on biomass estimates. Ecology 83:1026-1038.

Kochi, K. \& YanaI, S. 2006. Shredder colonization and decomposition of green and senescent leaves during summer in a headwater stream in northern Japan. Ecological Research 21:544-550.

KöNIG, R.; HePP, L. U. \& SANTOS, S. 2014. Colonisation of low- and highquality detritus by benthic macroinvertebrates during leaf breakdown in a subtropical stream. Limnologica 45:61-68.

KaushiK, N. K. \& Hynes, H. B. N. 1971. The fate of the dead leaves that fall into streams. Archiv für Hydrobiologie 68:465-515.

Li, A. O. Y.; NG, L. C. Y. \& DudgeOn, D. 2009. Effects of leaf toughness and nitrogen content on litter breakdown and macroinvertebrates in a tropical stream. Aquatic Science 71:80-93.

Ligeiro, R.; Moretti, M. S.; Gonçalves, J. F. Jr. \& Callisto, M. 2010. What is more important for invertebrate colonization in a stream with low-quality litter inputs: exposure time or leaf species? Hydrobiologia 654:125-136.

Mathuriau, C. \& Chauvet, E. 2002. Breakdown of leaf litter in a neotropical stream. Journal of the North American Benthological Society 21:384396.

Moretti, M. S.; Loyola, R. D.; Becker, B. \& Callisto, M. 2009. Leaf abundance and phenolic concentrations codetermine the selection of case-building materials by Phylloicus sp. (Trichoptera, Calamoceratidae). Hydrobiologia 630:199-206.

Mugnai, R.; Nessimian, J. L. \& Baptista, D. F. 2010. Manual de identificação de macroinvertebrados aquáticos do Estado do Rio de Janeiro. Rio de Janeiro, Technical Books. 174p.

Oliveira-Filho, A. T.; JARENKOW, J. A. \& RoDAL, M. N. J. 2006. Floristic relationships of seasonally dry forests of eastern South America based on tree species distribution patterns. In: Pennington, R. T.; Lewis, G. P. \& RATTER, J. A. eds. Neotropical Savannas and Seasonally Dry Forests. Plant Diversity, Biogeography and Conservation. Boca Raton, CRC Press, p. 159-192.

Pearson, R. G. \& Connolly, N. M. 2000. Nutrient enhancement, food quality and community dynamics in a tropical rainforest stream. Freshwater Biology 43:31-42.
Pes, A. M. O.; Hamada, N. \& Nessimian, J. L. 2005. Chaves de identificação de larvas para famílias e gêneros de Trichoptera (Insecta) da Amazônia Central, Brasil. Revista Brasileira de Entomologia 49:181-204.

Pettit, N. E.; Davies, T.; Fellman, J. B.; Grierson, P. F.; Warfe, D. M. \& DAVIES, P. M. 2012. Leaf litter chemistry, decomposition and assimilation by macroinvertebrates in two tropical streams. Hydrobiologia 680:6377.

R Development Core Team. 2012. R: A Language and Environment for Statistical Computing. R Foundation for Statistical Computing. Vienna, Austria. Available at https://www.R-project.org/.

Ratnarajah, L. \& Barmuta, L. A. 2009. The effects of leaf toughness on feeding preference by two Tasmanian shredders. Hydrobiologia 636:173-178

Rezende, R. S.; Petrucio, M. M. \& Gonçalves, J. F. Jr. 2015. The Effects of Spatial Scale on Breakdown of Leaves in a Tropical Watershed. PLOS ONE 9:e97072.

Rincón, J. \& MARTíneZ, I. 2006. Food quality and feeding preferences of Phylloicus sp. (Trichoptera: Calamoceratidae). Journal of the North American Benthological Society 25:209-215.

Schwarze, P. 1958. Phenole und chinome und die Bildung von Benzolkernen bei höheren Pflanzen.Encycl. Plant Physiology 10:507-542.

Tonello, G.; NaZiloski, L. A.; Tonin, A. M.; Restello, R. M. \& HepP, L. U. 2016. Effect of Phylloicus on leaf breakdown in a subtropical stream. Limnetica 35:243-252.

Tonin, A. M.; Hepp, L. U.; Restello, R. M. \& Gonçalves, J. F. 2014. Understanding of colonization and breakdown of leaves by invertebratesin a tropical stream is enhanced by using biomass as well as count data. Hydrobiologia 740:79-88.

Vannote, R. L.; Minshall, G. W.; Cummins, K. W.; Sedell, J. R. \& Cushing, C. E. 1980. The river continuum concept. Canadian Journal of Fisheries and Aquatic Sciences 37:130-137.

VAN SOEST, P. J. 1993. Use of detergents in the analysis of fibrous feeds. II. A rapid method for the determination of fibre and lignin. Journal Association of Official Analytical Chemists 46:829-835.

WAllace, J. B. \& WeBster, J. R. 1996. The role of macroinvertebrates in stream ecosystem function. Annual Review of Entomology 41:115139.

Wallace, J. B.; Eggert, S. L.; Meyer, J. L. \& Webster, J. R. 1997. Multiple trophic levels of a forest stream linked to terrestrial litter inputs. Science 277:102-104.

WANTZEN, K. M. \& WAGNER, R. 2006. Detritus processing by invertebrate shredders: a neotropical temperate comparison. Journal of the North American Benthological Society 25:216-232.

WeSTLAKE, D. F. 1963. Comparison of plant productivity. Biological Review 38:385-425.

Wright, M. S. \& Covich, A. P. 2005. Relative importance of bacteria and fungi in a tropical headwater stream: leaf decomposition and invertebrate feeding preference. Microbial Ecology 49:536-546.

Yule, C. M.; Leong, M. Y.; Liew, K. C.; RatnaRajah, L.; Schmidt, K.; Wong, H. M.; Pearson, R. G. \& Boyero, L. 2009. Shredders in Malaysia: abundance and richness are higher in cool upland tropical streams. Journal of the North American Benthological Society 28:404-415.

Zanon, M. M. F.; Goldenberg, R. \& Moraes, P. L. R. 2009. O gênero Nectandra Rol. ex Rottb. (Lauraceae) no Estado do Paraná, Brasil. Acta Botanica Brasilica 23:22-35. 